\title{
Effects of Inquiry Types on States Related to Community of Inquiry in Online Learning Environments: An Explanatory Case Study
}

\author{
Mustafa Serkan Gunbatar ${ }^{1}$ \\ Yuzuncu Yil University, Turkey \\ Tolga Guyer \\ Gazi University, Turkey
}

\begin{abstract}
The purpose of this study, with reference to Community of Inquiry, is to evaluate the comparative effectiveness of Learning activities based on Online Inquiry differentiating as Open and Guided Inquiries. This study employs mixed research method and explanatory design. The data were collected with the Community of Inquiry Index and the Student Process Survey. According to the Community of Inquiry index results, scores of all guided inquiry students in terms of the scale were higher at a statistically significant level than those of open group. Similarly, regarding the subscales of community of inquiry index teaching presence and cognitive presence factor scores were higher in favor of the guided inquiry students. There is no significant difference between the social presence scores of the groups. Obtained qualitative data also support this result. According to these findings, we can arrive at the conclusion that, within the scope of Community of Inquiry, the students in the guided inquiry group had a more efficient working process than the students in the open inquiry group.
\end{abstract}

Keywords: Online learning, Inquiry-based learning, Community of inquiry model, Open inquiry, Guided inquiry.

\section{Introduction}

One of the most important factors that should be considered in contemporary educational environments is the learning concept. Constructivist approach is one of the theories that attempt to explain human learning and it's still up to date. This approach focuses on the transformation of knowledge into learning building on their previous learning.

One of the methods including the elements of constructivist learning environments is Inquiry Based Learning (IBL) (Yurdakul, 2005). IBL is the process of active learning with questioning, researching and understanding the logic of knowledge (Jansen, 2011). IBL is applied in all courses at all stages of education from kindergarten to university (Arslan, 2007). Different fields such as science, history, and engineering have used inquiry approaches in different contents. Online inquiry is a special kind of inquiry where the inquiry is carried out with interconnected cognitive activities like (a) formulating a research question (b) digital records research for relevant

\footnotetext{
${ }^{1}$ The article is a part of the first author's doctoral dissertation.
} 
information (e.g., articles, websites, images, graphics, and raw data sets) (c) an assessment, reading and logical understanding of the information found, and (d) consistently unifying the different parts of the information in order to answer the initial question (Quintana, Zhang \& Krajcik, 2005). Even though IBL has been adopted in student-centered education, constructivist educational processes and various other applications, there is uncertainty about how it has to be carried out and the teacher's role in the process. Thus, some experts have stated that there are several different types of processes that take shape according to some circumstances in the course process (Caliskan, 2008). We can examine these types under three headings: Open, Guided, and Structured inquiries (Altunsoy, 2008; Caliskan, 2008; Kula, 2009; Tatar, 2006). If we examine them in terms of the degree of guidance provided by teachers, we can talk about two kinds: Open and Guided ones (Lim, 2001). In guided inquiry, teachers take more responsibility compared to open inquiry. In open inquiry, the inquiry is entirely student-centered (Duban, 2008). What can be done to guide students in the online inquiry process are as follows: Providing an integrated working space; making implicit activities in online inquiry more explicit; supporting online inquiry planning and ongoing monitoring; and minimizing workload of mechanical activities in online inquiry (Zhang \& Quintana, 2012). Guided inquiry process can be carried out in the framework of these criteria.

In cases where the students are not ready perform activities on their own, they should be guided. Open inquiries can be carried out in a more healthy and productive way in secondary and tertiary education where the students can work independently and have the necessary knowledge and the skills (Caliskan, 2008). But answering all of the questions attached to our mind in all disciplines and accessing knowledge in the online learning environment is a totally different issue and should be studied in comparison.

Community of Inquiry (COI) investigates the effects of the interactions students have with each other, and their interaction with the teacher on the effectiveness of online and blended learning environments. COI is a model laid down by Garrison, Anderson, and Archer (2000) and aims to guide teachers to facilitate educational process where communication is carried out via the computer.

In order to understand the dynamics of the online learning environments, COI offers a collaborative constructivist perspective (Arbaugh, Cleveland-Innes, Diaz, Garrison, \& Ice, 2008). $\mathrm{COI}$ is a useful model for research to guide their online learning (Garrison, 2007) and used at a significant rate at the creation and evaluation of online learning environments (Ozturk, 2012). $\mathrm{COI}$ with teaching, cognitive, and social presences subscales could differ according to some educational contexts and must be investigated in different contexts (Yang, 2016). The teaching presence is in relation to teachers' performance (Szeto, 2015). For example, instructors who engage students in the communicative process of learning achieved higher levels of teaching presence (Wisneski, Ozogul, \& Bichelmeyer, 2015) or when the formal instructor is not present, knowledge of cognition is enhanced and students are involved in more metacognitive monitoring activities (Garrison \& Akyol, 2015). Therefore, teaching presence plays a central role in establishing and facilitating cognitive and social presences (Ma, Han, Yang, \& Cheng, 2015). Within the scope of this study, rich information regarding the behavior of the students who participated in open and guided inquiry, teacher behavior and student use of the COI index will be provided. This research is also helped to provide information about communication processes of participants with other individuals in different treatment groups. 


\section{Theoretical framework}

\section{Community of Inquiry Model (COI)}

The origin of COI goes back to John Dewey's work. It is related to the constructivist approach in higher education (Akyol, et al., 2009; Garrison, 2007). Dewey believed that inquiry was a social action and the basis of the educational experience (Garrison, Anderson \& Archer, 2010).

$\mathrm{COI}$ was coined as a special form of communication performed through computers in higher education. Traditionally, it is based on asynchronous text-based discussion groups rather than where they work independently (Garrison, Anderson, \& Archer, 2010). It is a model frequently used in defining, and evaluating the effectiveness of learning situations taking place in online and blended learning environments (Ozturk, 2012) moreover, it is a leading teaching model used in these environments (Akyol, et al., 2009). COI assumes that learning occurs owing to the community formed by interaction of three core elements namely cognitive presence, social presence, and teaching presence (Garrison,et al., 2000). In the next part, there core elements will be explained in detail.

\section{Cognitive Presence}

The most basic element of $\mathrm{COI}$ that is crucial for success in higher education is cognitive presence. This element means that the learner as a part of the research community constructs meanings during the ongoing communication. Cognitive presence is vital for critical thinking process, and critical thinking skills that often expressed in higher education (Garrison, Anderson \& Archer, 2000).

Cognitive presence is defined within COI. Critical thinking is based on the literature and gains functionality with practical inquiry. Critical thinking includes creativity, problem solving, intuition, and understanding situations. With this perspective Garrison, Anderson, and Archer (2000) have presented the practical inquiry model which is a guide to measure cognitive presence in online environment (Garrison, Anderson \& Archer, 2001).

Cognitive presence is also defined as researching, constructing, analyzing, and verification with collaboration and projection within the COI. Practical inquiry model is based on the reflective thinking studies of Dewey. Cognitive presence is defined by the practical inquiry cycle. In practical inquiry, participants understand the problem or situation by following the research, integration, and application steps in a planned manner (Garrison, 2007). The stages of the practical inquiry model are, triggering event, exploration, integration, and resolution (Figure 1) (Garrison, et al., 2010). 


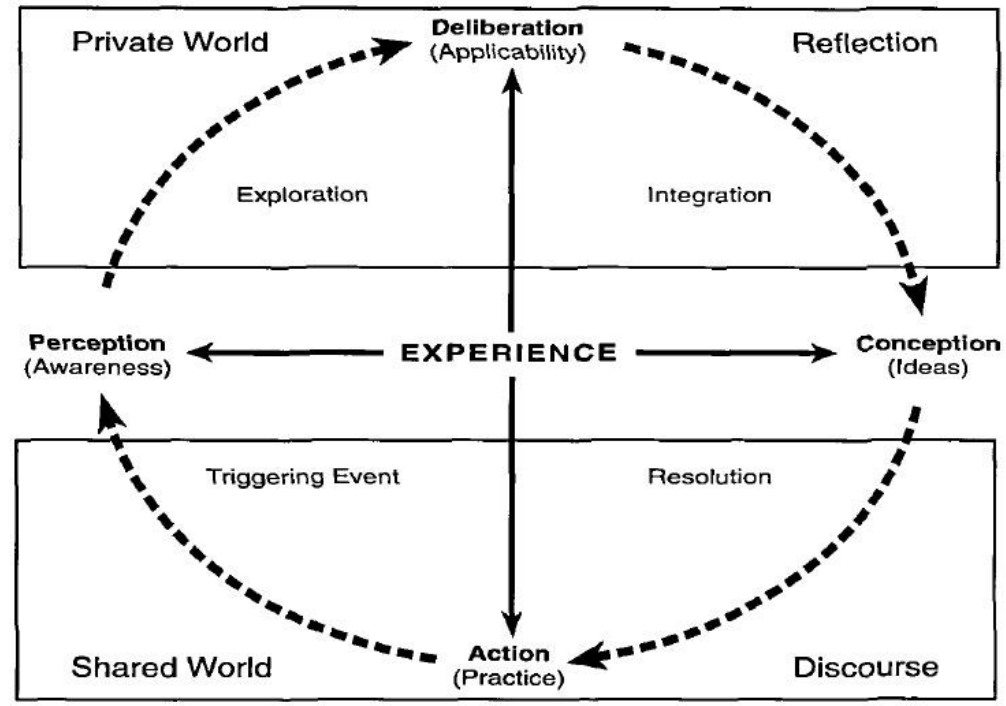

Figure 1. Practical Inquiry Model

Understanding the world of the learner is very important in creating cognitive presence to support educational purposes. The first dimension of the model (see Figure 1) reflects the continuity between deliberation and action. The second dimension represents the transition between concrete and abstract worlds, which is the perception-conseption aspect. These are the cognitive processes that combine facts and ideas. Practical inquiry model identifies four basic steps to understand and identify cognitive presence in the educational context. These steps are described below (Garrison, et al., 2001).

The first stage of the model (i.e., bottom left quarter) reflects the initial phase of critical inquiry and is known as the event triggering event. Here, there is a matter arising from experience, dilemmas or problems. In educational context, teachers establish a clear link to learning difficulties or the tasks, which becomes the triggering event. However, in more democratic and non-hierarchical applications, any group member can take over the event trigger job. The critical role of the teacher is to start the triggering event, shape, and in some cases confuse students. Thus, the focus remains on achieving the educational outcomes.

The second stage of the process is exploration. At this stage, participants transform their reflective thoughts resulting from individual and social researches from private to projective. At the beginning of this phase, students are expected to understand and perceive the nature of the problem, and then to research for more relevant information. At the end of this stage, students begin to be selective about the problem and what is relevant to the subject or not.

The information generated in the third phase (i.e., integration phase) of the research is related to the construction of the information. In the transition from the research stage, students begin to assess the feasibility of ideas. Integration of ideas and the construction of meaning must arise from the communication within the research sample. This stage requires active teaching presence for understanding misconceptions and asking in-depth questions. As a result, teaching presence is essential for moving to more advanced stages of critical thinking and cognitive development.

The fourth stage is the resolution phase that is the process of critically evaluating the concepts. Therefore, it promises solutions and testing their validity. Generally it requires testing with 
agreement within the research sample and experiences. This phase requires clear expectations and possibilities for the implementation of the newly created knowledge. Ideally, at the end of this phase, students are expect to achieve useful information, then the group passes to a new problem.

Cognitive presence, is as important as the educational process. Individuals should feel comfortable with each other. Cognitive presence is not sufficient to sustain "critical learning" communities by itself. Critical learning communities should be recharged with the communicative functions of the broader social-emotional environment. High degrees of connection and participation accompanying high levels of social presence are required for the development of the higher level thinking skills and tasks based on the collaboration (Garrison, et al., 2000).

To conclude, practical inquiry model reflects the critical thinking process (i.e., a tool for the formation of cognitive presence) (Garrison, Anderson, \& Archer, 2001).

\section{Social Presence}

The second core element of $\mathrm{COI}$ is social presence that is the ability of the participants to reflect their own personal character to the COI. Social presence can also be defined as the ability of the person to maintain personal/logical relations and the planning oneself (Garrison, 2007). Thus, they present themselves to other participants as "real people". Primary importance of this element is related to support it provides to cognitive presence (Garrison, Anderson \& Archer, 2000).

There are three categories of social presence, namely emotional expression, open communication, and group cohesion. First, emotions are in close connection with the task maintaining and task motivation. Therefore they are also in close connection with the critical inquiry. Second, humor and self-disclosure are examples of emotional expressions that keep people together in a community. Open communication can be defined as mutual and respectful exchange. Common awareness and open recognition are examples of open communication. Common awareness forms the group loyalty. Common awareness begins with evidence of the existence of others and their participation in the messages. Self-esteem and impression management issues are the aspects of the public awareness. Shared awareness has a lot to do with listening interpretations and the contributions of others in a respectful manner. Recognition that nourishes the exchange and maintenance of relationships is the second example of open communication. A clear appreciation, encouragement, adaptation as its complement are text-based tools for recognition, and support in communication. This aspect of social presence is especially important in text based environments where there is no gesture and facial expression. The third category of social presence is group cohesion. This category can be exemplified with the formation and expression of group feelings. This supports the educational process and is completely associated with cognitive processes. The quality of critical inquiry and the discourses reaches the appropriate level when the students see themselves as members of a group. Belonging to the group and establishing commitment is important to share personal meaning. In summary, social presence, reflects supportive conditions to emotional expression, open communication, and group cohesion to build meaning (Garrison, Anderson \& Archer, 2000). 
Social presence refers to a qualitative differentiation between community-based inquiry and the simple function of gathering knowledge. If social presence can be integrated with an appropriate teaching presence, the result may be a productive critical inquiry resulting from a high level of cognitive presence (Garrison, et al., 2000).

\section{Teaching Presence}

Teaching presence can be defined as being akin to managing an orchestra in an online environment (Shea et al., 2010). Instructional presence consists of two general functions. First is designing the educational process. In an educational environment, primarily teachers are responsible for this function. However, any individual within the research community can undertake this responsibility. These responsibilities include selecting and presenting lesson content. In addition, they include design, development, and measurement of learning activities. Typically teachers carry out these functions. The second function is facilitation. This responsibility can be shared by teacher and students or some of students. Sharing facilitation function is suitable for higher education. It is also usual for a computer based communication in learning environment. In both cases, teaching presence is a tool used for realizing educational outputs by improving social and cognitive presence (Garrison, et al., 2000).

Teaching presence has three indicators that are independent from each other. There are instructional management, building understanding and direct instruction (Garrison, 2007; Garrison, et al., 2000).

Instructional management includes topics about planning before, during, and after educational process. It employs setting the curriculum, designing the method and measurement type, time management, and making use of educational environment. In educational context, building understanding is related to obtaining productive and valid information. Being challenging and stimulating, this process is essential for creating and maintaining COI. This indicator is closely related to academic integration of collaborative learning community. This is a process for sharing the meaning, defining agreed and disagreed areas, and creating a group consciousness for coming to an agreement and understanding. During instructor's active intervention, the instructor makes inactive participants contribute, acknowledges individual contributions, reinforces appropriate contributions, focuses on discussion, and generally facilitates educational process. In direct instruction indicator, instructors' responsibility includes facilitating reflection of content by presenting questions. In addition, it is also the instructor's responsibility to provide feedback by guiding and summarizing discussions. This indicator requires the instructor to have appropriate level of content knowledge (Garrison, et al., 2000).

Teaching presence holds an important place for determining satisfaction of students, perceived learning, and sense of community. While communication and discourse play key roles in high level thinking skills, it can't achieve its goals without structure and leadership (facilitation and direct instruction) (Garrison, 2007).

The binding element for creating educational research community is teaching presence. Appropriate cognitive presence, social presence, and ultimately providing critical research community depends on the instructor's presence. This is especially true in cases where computer is the primary communication tool (Garrison, et al., 2000). 


\section{Aim of the study}

With reference to $\mathrm{COI}$, the main aim of the study is compare and contrast effectiveness of Online Inquiry processes namely, Open and Guided Inquiries. Sub-objectives of the study can be stated as follows:

a. To determine whether Teaching, Social, and Cognitive presence of groups students differ by inquiry type (i.e., open and guided).

b. To obtain qualitative data about students' communications with their peers and instructor.

\section{Material and methods}

\section{Research Model}

This study employs mixed research method and explanatory design, in which researcher first use quantitative method followed by qualitative method to have details about quantitative data he/she obtains (Fraenkel \& Wallen, 2009). The predictive variable in this study is inquiry type (i.e., open inquiry and guided inquiry) while predicted variables are states of research sample (i.e., teaching presence, social presence, and cognitive presence).

\section{Work Group}

Research sample consists of sophomore students of Gazi University, Faculty of Education, Computer Education and Instructional Technology department. They took Material Design and Usage in Education lesson during 2013-2014 academic year (i.e., fall semester). This group was chosen because it is easily accessible. In total, there are 56 participants, 32 of whom were female and 24 of whom were male. Students were grouped into two equal groups according to their level of motivation towards the course. 28 students were included in open inquiry process while 28 of them were included in guided inquiry process.

In small groups, discussion and learning satisfaction are higher than in large groups (Shaw, 2013). Additionally, in online learning environments, it has been observed that groups of 2 to 6 people are formed in collaborative learning activities (Coll, Rochera \& Gispert, 2014; Oliveira, Tinoca \& Pereira, 2011; Remesal \& Colomina, 2013; Shaw, 2013). That's way students were again divided into small work groups, each consisting of 5 or 6 people. Heterogeneous small working groups were established in terms of gender and motivation levels for the course. A total of 10 work groups were formed. Five of them were included in open inquiry process and the remaining five were included in guided inquiry process.

\section{Data Collection Tools}

\section{Community of Inquiry Index}

In order to obtain information about participants' communication among themselves and with the instructor in online environment, Community of Inquiry (COI) index was used. For measuring these characteristics related to students' interactions, namely, teaching presence, social 
presence, and cognitive presence, we used $\mathrm{COI}$ index which was adapted to Turkish literature by Ozturk (2012). The scale consists of three sub dimensions and 34 items. Reliability of the scale was measured by Cronbach Alpha internal consistency coefficient which was based on item analysis and following values were calculated: 0.92 for Teaching presence, 0.88 for Social presence, 0.75 for Cognitive presence, and 0.97 for the entire scale. The factor structure of the scale was analyzed with the Confirmatory Factor Analysis (CFA). According to CFA, $\chi 2=996.25$ $(s d=524 ; p<0,001) ; \chi 2 / s d=1,90 ;$ SRMR=0,072; GFI=0,70; $A G F I=0,66 ; R M S E A=0,081 ; C F I=0,81$; and $\mathrm{NNFI}=0,80$ values were determined. In light of this data, the scale which was adapted by Ozturk (2012) is suitable for Turkish culture and has validity and reliability to be used in Turkish language.

\section{Student Process Survey}

In order to gather qualitative data about inner-group communications of participants involved in Open and Guided Inquiry processes and about their communications with the instructor, data collection tools consisting of four questions were used. The four questions are as follows:

1. Have you encountered a problem with the instructor or with your group peers during the group work? if so, please specify.

2. A. What are your opinions about instructor's support while conducting your work? (for open inquiry)

B. What do you think about the positive and negative effects of instructor's guidance on your group's performance and/or on you, while you carry out group work or personal work? (for guided inquiry)

3. What do you think about your personal communication with instructor while you conduct your work?

4. What do you think about the process of your instructor's communication with the group?

\section{Learning Materials}

Learning activities carried out within the scope of this research were conducted using free, open source, Moodle based Learning Management System. Prepared learning material was reviewed by two experts. After necessary modifications were made, learning material became ready for application. Learning material was designed to allow collaborative learning and was practiced within an ill structured problem situation framework which offers learning activities to students. Between September 27, 2013 and November 29, 2013, six learning sessions covering nearly two months were carried out. On the date of midterm exam, November 15, 2013, students' opinions were taken using Student process survey. One week after that, on November 22, 2013, data were collected using $\mathrm{COI}$ index in online environment.

\section{Results}

For determining whether $\mathrm{COI}$ index scores after learning process show normal distribution or not, Shapiro-Wilk test was used. Total score of the scale, Teaching presence scores, and 
Cognitive presence scores show normal distribution ( $p>0.05)$. However, Social presence scores of the Open inquiry show a negatively skewed distribution. This negatively skewed distribution was turned into a positively skewed distribution and logarithmic conversion was applied (Buyukozturk, 2010). Following these actions, it was observed that Social presence measurements also show normal distribution ( $p>0.05)$. Therefore, we decided to use parametric statistical techniques.

\section{Comparison of Students by Inquiry Type of Community of Inquiry Index and Its Sub-scales}

Table 1. t-test Results Where Students Were Compared After Application by Inquiry Type of COI Index and Its Sub-scales (Open and Guided Inquiries)

\begin{tabular}{|c|c|c|c|c|c|c|c|}
\hline & Group & $\mathrm{N}$ & $\bar{x}$ & SS & $\mathrm{Sd}$ & $\mathrm{t}$ & $p$ \\
\hline \multirow{2}{*}{ COI index total score } & Open & 28 & 3.05 & 0.50 & \multirow{2}{*}{54} & \multirow{2}{*}{2.412} & \multirow{2}{*}{$0.019 *$} \\
\hline & Guided & 28 & 3.32 & 0.32 & & & \\
\hline \multirow{2}{*}{ Teaching presence } & Open & 28 & 3.07 & 0.55 & \multirow{2}{*}{54} & \multirow{2}{*}{2.724} & \multirow{2}{*}{$0.009 *$} \\
\hline & Guided & 28 & 3.41 & 0.39 & & & \\
\hline \multirow{2}{*}{ Social presence } & Open & 28 & 3.09 & 0.59 & \multirow{2}{*}{54} & \multirow{2}{*}{1.096} & \multirow{2}{*}{0.278} \\
\hline & Guided & 28 & 3.23 & 0.36 & & & \\
\hline \multirow{2}{*}{ Cognitive presence } & Open & 28 & 2.00 & 0.55 & \multirow{2}{*}{54} & \multirow{2}{*}{2.247} & \multirow{2}{*}{$0.029 *$} \\
\hline & Guided & 28 & 3.28 & 0.37 & & & \\
\hline
\end{tabular}

$* p<0.05$

When Table 1 is examined, COI index scores of students in Guided Inquiry group are statistically significantly higher than those of open group $\left(t_{(54)}=2.412, p<0.05\right)$. Parallel to this, Teaching presence $\left(t_{(54)}=2.724, p<0.05\right)$ and Cognitive presence $\left(t_{(54)}=2.247, p<0.05\right)$ sub-scales were found to be in favor of Guided Inquiry group. However, it was observed that there is no statistically significant difference between groups regarding Social presence sub-scale $\left(t_{(54)}=1.096, p>0.05\right)$. The reason for cognitive presence sub-scale was higher in favor of guided inquiry group can be an indication of the fact that students in this group can form the structure of learning content better than those in open inquiry group. For the reason of the difference in teaching presence sub-scale, it can be stated that instructor's changing role (by the groups) might be a factor. That fact that there is no statistically significant difference between groups within the context of social presence can be a result of both groups utilized similar collaborative activities for learning.

\section{Opinions of Participants Regarding Their Communication during Treatment Process}

In order to gather information about inner-group communications of participants and communication between work group and instructor, data were collected through use of Student Process Survey consisting of four questions. First, the results for open IBL group were summarized in Table 2, 3, 4, and 5. Then, Table 6, 7, 8, and 9 presented results for Guided IBL group.

\section{Opinions of Participants in Open IBL Group}

In this subheading, analysis of the data gathered from Open IBL group was presented. 
Table 2. Themes Related to the Question about the Problem with either Instructor or Peers During Group Work.

\begin{tabular}{cl}
\hline Themes & Frequency \\
\hline$\checkmark$ Not to encounter any problem & 9 times \\
$\checkmark$ Inner-group communication problems & 9 times \\
$\checkmark$ Work plan and assignment of tasks & 6 times \\
$\checkmark$ To have trouble while clarifying the problem situation & 5 times \\
$\checkmark$ Communication with instructor & 2 times \\
$\checkmark$ Incompetencies in the information search on the internet & 2 times \\
\hline
\end{tabular}

When Table 2 is examined, it can be seen that nine of Open IBL students mentioned about not to encounter any problem. However, nine participants talked about inner-group communication problems for instance "At first, we didn't understand how to communicate with the instructor and what we were asked to", "Some of our peers claim that they know the subject matter better than us have caused discomfort in the group". These themes are followed by Work plan and assignment of tasks were mentioned 6 times by students. For example, "We have had problems in distribution of tasks" or "We've had problems while identifying and practicing the steps we were to take". Students talked about clarifying the problem situation five times. Finally, the theme of Communication with instructor and Incompetencies in the information search on the internet were also stated two times.

Table 3. Themes Related to the Instructor's Support while Conducting Their Work

\begin{tabular}{cll}
\hline Themes & Frequency \\
\hline$\checkmark$ & Observing but not intervening & 16 times \\
$\checkmark$ & Instructor helps, when we need it & 15 times \\
$\checkmark$ & Informing about the learning process & 7 times \\
$\checkmark$ & Unsufficient guidance level & 4 times \\
$\checkmark$ & Providing a free work environment & 4 times \\
$\checkmark$ & Sufficient guidance level & 1 times \\
\hline
\end{tabular}

According to Table 3 the most stated expression was about the inadequate intervention of instructor by 16 participants. This theme consists of expressions like "He has followed us in synchronous conversation environment", "He has not participated in our work and discussions much". This theme was followed by the help of the instructor when needed and mentioned 15 times. For example, many students have used the expression "He has answered my questions". Students mentioned 7 times that the instructor informed them about their learning process. Insufficient guidance level and providing a free work environment themes have been mentioned four times. Lastly, one participant mentioned that the guidance was sufficient.

Table 4. Themes Related to the Personal Communication with Instructor Conducting Work

\begin{tabular}{cll}
\hline Themes & Frequency \\
\hline$\checkmark$ & No personal communication ever & 8 times \\
$\checkmark$ & Inadequate personal communication & 6 times \\
$\checkmark$ & Easy access to the instructor & 6 times \\
$\checkmark$ & Getting answers to the questions asked & 6 times
\end{tabular}




\begin{tabular}{cll}
\hline Themes & Frequency \\
\hline$\checkmark$ & No communication unless necessary & 3 times \\
$\checkmark$ & Invitation to join the learning session & 2 times \\
\hline
\end{tabular}

Table 4 shows that eight of Open Inquiry students had never personally contacted the instructor and six of them rarely had. When other statements were examined, it was observed six times "contacting the instructor easily" and "getting answers to their questions" themes. The situation of no communicate unless necessary referenced three times and "Invitation to join the learning session" for two times.

Table 5. Themes Related to the Process of Instructor's Communication with the Group

\begin{tabular}{cll}
\hline Themes & Frequency \\
\hline$\checkmark$ & How the communication between the work group and & 20 times \\
& the instructor was & 7 times \\
$\checkmark$ & Communication meets expectations & 7 times \\
$\checkmark$ & Answer the questions asked & 6 times \\
$\checkmark$ & Inadequate communication & 6 times \\
$\checkmark$ & Not to communicate from synchronous meeting section & 4 times \\
$\checkmark$ & No intervention to the group studies
\end{tabular}

When Table 5 is examined, seven of the participants from this group stated that communication with instructor meet their expectations. However, six of them thought that communication was inadequate.

\section{Opinions of Participants in Guided IBL Group}

In this subheading, analysis of the data gathered from Guided IBL group was presented.

Table 6. Themes Related to Problems Encountered with the Instructor or with Peers During the Group Work

\begin{tabular}{cll}
\hline Themes & Frequency \\
\hline$\checkmark$ & Not to encounter any problem & 20 times \\
$\checkmark$ & "getting used to" problems experienced in first weeks & 4 times \\
$\checkmark$ & Inner group communication problems & 2 times \\
$\checkmark$ & Problems with the instructor & 1 times \\
\hline
\end{tabular}

When Table 6 is examined, it can be seen that 20 of Guided IBL students didn't encounter any problems. When other statements were examined, it was observed that problems mostly were about the "getting used to" problems experienced in first weeks (expressed four times). Regarding to this theme students used expressions like "At first, while we were clarifying the problem, we couldn't focus on what the other wrote as we were writing at the same time in synchronous conversation environment", "We've had doubts about what we were going to do and how to discuss during first few weeks". Two students have stated problems about innergroup communications. One student has stated that he/she got an unexpected response from the instructor to his/her question. 
Table 7. Themes Related to the Positive and Negative Effects of Instructor's Guidance on Group's Performance and/or Personal Performance

\begin{tabular}{|c|c|c|}
\hline Themes & & Frequency \\
\hline$\checkmark$ & Positive contribution to group work & 20 times \\
\hline$\checkmark$ & Positive contribution to learning process & 11 times \\
\hline$\checkmark$ & Positive effect on group work and individual research & 10 times \\
\hline$\checkmark$ & Positive contribution to individual performance & 2 times \\
\hline
\end{tabular}

When Table 7 is examined, it can be seen that 20 of Guided Inquiry students have stated that instructor's guidance has a positive effect on group work. Students reflected positive contributions to group work such as "The instructor has enabled us to progress step by step", "The instructor enabled us to progress faster" etc. Students used 11 expressions related to the positive contribution to the learning process. They stated: "Thanks to instructor's guidance, process progressed correctly", "The instructor enabled us to understand the subject better" in relation to this theme. The third most frequently mentioned theme is Positive effect on group work and individual research. This situation has been mentioned 10 times. Two participants also mentioned positive contribution to individual performance.

Table 8. Themes Related to Personal Communication with Instructor while Working

\begin{tabular}{cll}
\hline Themes & Frequency \\
\hline$\checkmark$ & How to consult & 14 times \\
$\checkmark$ & Easy reach to the instructor & 8 times \\
$\checkmark$ & Help provided & 7 times \\
$\checkmark$ & Not to have any problem & 5 times \\
\hline
\end{tabular}

According to Table 8, participants with regard to Easy reach to the instructor theme 8 students expressed like "I've received prompt answers when I've consulted him", "I was able to get answers to my questions" expressions. Help provided theme was mentioned 7 times like "He helped me to realize my own shortcomings in the research process", "He enabled me to work effectively while clarifying the problem" expressions. Five students stated that they did not have any problems at the point of personal communication.

Table 9. Themes related to the Question "What Do You Think about the Process of Your Instructor's Communication with the Group?"

\begin{tabular}{|c|c|c|}
\hline Theme & & Frequency \\
\hline$\checkmark$ & How was the communication & 22 times \\
\hline$\checkmark$ & Positive aspects of communication & 11 times \\
\hline & $\begin{array}{l}\text { To communicate with students as if he was part of their } \\
\text { group. }\end{array}$ & 8 times \\
\hline
\end{tabular}

When Table 9 is examined, it can be seen that most expressed situation by Guided IBL students is how the communication was. This situation has been mentioned 22 times. This theme has been revealed as "Had been commenting via online communications environment", "Has given weekly feedback about our work", "We are constantly communicating" expressions. 11 times 
the positive aspects of communication have been mentioned like "We have a good communication", " His close attendance to our group and guidance had a positive effect on the process" statements. Except those themes related to this subject is about that instructor was communicating with them as if he was part of the group (expressed by eight participants).

\section{Conclusion and Discussion}

This study, in which different learning processes differ according to the type of inquiry, has been compared within the framework of the community of inquiry. Qualitative data about the communication processes within the learning process have been obtained. Also after application processes for guided and open IBL groups, within the context of COI index as well as its subscales Teaching presence and Cognitive presence showed a differentiation in favor of Guided inquiry group. For social presence, one of the sub-scales, no statistically significant difference was found among the inquiry groups.

College students who continue their work within a framework of a certain discussion protocol and in online, asynchronous discussion environment are more successful in creating and maintaining an online research community than students in the Open Inquiry group. Participants who carry out their work activities according to certain rules have contributed more in terms of cognitive, social and teaching presence (Zydney, deNoyelles, \& Seo, 2012). This result is consistent with the context of our total scale score, Teaching presence, and Cognitive presence aspects. However, it shows no differences on Social presence aspect. In the learning environments where direct instruction is made, Social presence is totally related to Teaching presence (Lim \& Richardson, 2016) but especially in constructivist learning environments there are collaborative learning and group work. Online social activities increase parallel to the complexity of the learning task (Morueta, López, Gómez \& Harris, 2016). Additionally, discussions are major and growing players in online learning environments (Kent, Laslo, \& Rafaeli, 2016). Students can work collaboratively based on asynchronous discussion forums and synchronous chat rooms (Yang, 2016) and social presence is formed as a result of a collaborative study (Shea \& Bidjerano, 2012). Social presence can be examined under two dimensions: Peer (student) social presence and instructor social presence (Turel, 2016). Therefore, it can be possible that both groups (i.e., open inquiry and guided inquiry) have developed similar social presences due to both groups studied collaboratively. The open inquiry group's social presence can be based on peer social presence and the guided inquiry group's social presence can be based on instructor social presence.

When Open and Guided IBL groups were compared regarding "problems with the instructor or group peers during group work", it can be seen that participants of Open IBL group have stated that they have more problems with inner-group communications. On the other hand, Guided IBL students have stated that they had problems in the first few weeks of the course. Nine of Open IBL students and 20 of Guided IBL students have stated that they haven't encountered any problems. Obtained information is similar to $\mathrm{COI}$ index Cognitive presence sub-scale results. In the online constructivist learning environments, teachers focus on collaboration to provide cognitive presence on the learners (Kozan, 2016). Knowledge construction is a socio-cognitive process (Shea, Hayes, Uzuner-Smith, Gozza-Cohen, Vickers, \& Bidjerano, 2014) and cognitive presence occurs with realization of content as a result of collaborative activities. The fact that Open IBL students' Cognitive presence is lower than those of Guided IBL ones may be due to their experience with inner-group communication problem. 
When students' opinions regarding "support and guidance that the instructor provided" were examined for both Open IBL and Guided IBL groups, it can be seen that all participants in the Guided IBL group stated positive opinions. Likewise, it was also observed that participants in Open IBL group mostly expressed positive opinions. According to Turel (2016), positive feelings or satisfaction are related to how well social interactions are established, both among students, and between students and instructor. This result is consistent with the insignificants difference between the groups' social presence measurements. In open IBL group, there were also some conflicting statements regarding contribution of the instructor. The guidance of the instructor suggests teaching presence. Obtained data about statistically significant difference in favor of the guided group in teaching presence shows similarity with partial negative thoughts of Open IBL group students. Three presences (i.e., teaching, cognitive, and social) could differ across educational and cultural contexts (Yang, 2016) and there may not be significant correlation between Teaching Presence and Social Presence (Shea, Hayes, Uzuner-Smith, Gozza-Cohen, Vickers, \& Bidjerano, 2014). Therefore, it is considered that the data obtained within the scope of the study are consistent with each other.

When participants' opinions about their individual communication process with the instructor were examined comparatively, it can be seen that opinions of participants in Open IBL group are mostly about the amount of communication with the instructor while opinions of Guided IBL students are mostly about the content and characteristics of those communications. With the guidance of the instructor, students focus on learning activities (Scott, Sorokti \& Merrell, 2016) and Instructor's guidance has a significant impact on students' completing the learning task (Ma, Han, Yang \& Cheng, 2015). In accordance with this, Guided IBL students talked about the consultation they received while performing their learning activities. This is seen as a normal situation which is a result of difference in the rate of communications especially during guidance.

When Open and Guided IBL group students' opinions about Instructor's communication with work groups were examined, both groups often talked about how the communication process worked. Open IBL groups mentioned that they could take answer the questions they asked and their asynchronous communication. Guided inquiry groups mentioned that they are in constant communication via online communication tools. Differently, some Open IBL group students have expressed some expectation as opposed to Guided IBL group students show that students expected the instructor to intervene more. Choice of different contents and tools in teaching process (i.e., static content or discussions and different uses of the available tools) suggests a need for different instructional interventions (Kovanović, Gašević, Joksimović, Hatala \& Adesope, 2015) and use of engagement tools (i.e., live chat, discussion forums etc.) is important in order to enhance learning outcomes and teaching presence (Yang, Quadir, Chen \& Miao, 2016). The differentiation of teaching presences in favor of the Guided IBL groups and the open IBL groups' desire to have more teacher intervention to the learning process findings obtained in the study are complement each other.

When participants' opinions regarding instructor's communication with work groups as well as individually with students, it was observed that some participants in the Open IBL group are in need of more communication. This is consistent with the difference in teaching presence subscale in favor of Guided IBL group. 


\section{Limitations and Recommendations}

While this study contributes to the field of education technologies, there are some limitations that should be expressed. First, the study was conducted with participants enrolled to only one institution. New studies can be carried out with different participants and with more participants.

Within the scope of this study, teaching, cognitive and social presences have been taken into consideration. However, learning presence variable that has recently begun to be named in recent times can also be considered in new studies to be done.

When the Open IBL group participants' opinions about support and guidance provided by the teacher were examined, participants mostly expressed positive opinions but there are also some conflicting statements. This may be due to different expectations and individual differences. Hence, it should be subject of a new study.

When Open IBL group participants' opinions about Instructor's communication with work groups were examined, some participants had an expectation that instructor would take more role. This situation should also be examined in new studies by taking individual differences into account.

Finally, as total COI index scores of Guided IBL students, "cognitive presence" scores which "remains focus of teaching process and enables systematic handling of topics" and teaching presence score which is related to "organizing learning environment for facilitating knowledge gathering" statistically significantly differ from students in Open IBL group, it can be suggested that guided research and work should be used for teaching sessions/application which will take place online in teacher education.

\section{References}

Akyol, Z., et al. (2009). A Response to the review of the community of inquiry framework. Journal of Distance Education, 23(2), 123-136.

Altunsoy, S. (2008). Ortaöğretim biyoloji ogretiminde arastirmaya dayalı ogrenme yaklasiminin ogrencilerin bilimsel surec becerilerine, akademik basarilarina ve tutumlarina etkisi (Unpublished master's thesis). Secuk University, Konya.

Arbaugh, J. B., Cleveland-Innes, M., Diaz, S. R., Garrison, D. R., Ice, P., Richardson, J. C., \& Swan, K. P. (2008). Developing a community of inquiry instrument: Testing a measure of the community of inquiry framework using a multi-institutional sample. The Internet and Higher Education, 11(3), 133-136.

Arslan, A. (2007). Fen egitiminde araştirmaya dayali ogretim yonteminin kavramsal ogrenmeye etkisi (Unpublished master's thesis). Marmara University, Istanbul.

Buyukozturk, S., Akgun, O. E., Ozkahveci, O., \& Demirel, F. (2004). The validity and reliability study of the Turkish version of the Motivated Strategies for Learning Questionnaire. Educational Sciences: Theory \& Practice, 4(2), 231-237.

Buyukozturk, S. (2010). Sosyal bilimler icin veri analizi el kitabi (20 th ed.). Ankara:Pegem A. 
Coll, C., Rochera, M.J. \& Gispert, I. (2014). Supporting online collaborative learning in small groups: Teacher feedback on learning content, academic task and social participation. Computers \& Education, 75, 53-64.

Caliskan, H. (2008). Ilkogretim 7. sinif sosyal bilgiler dersinde arastirmaya dayali ogrenme yaklasiminin derse yonelik tutuma, basariya ve kalicilik duzeyine etkisi (Unpublished doctoral dissertation). Gazi University, Ankara.

Duban, N. (2008). Ilkogretim fen ve teknoloji dersinin sorgulamaya dayali ogrenme yaklasimina gore islenmesi: Bir eylem araştirmasi. (Unpublished doctoral dissertation). Anadolu University, Eskisehir.

Freankel, J.R. \& Wallen, N. E. (2009). How to design and evaluate research in education. (7th. ed.). New York: McGraw-Hill.

Garrison, D. R. (2007). Online community of inquiry review: Social, cognitive, and teaching presence issues. Journal of Asynchronous Learning Networks,11(1), 61-72.

Garrison, D. R., Anderson, T., \& Archer, W. (2000). Critical inquiry in a text-based environment: Computer conferencing in higher education. The Internet and Higher Education, 2(2), 87105.

Garrison, D. R., Anderson, T., \& Archer, W. (2001). Critical thinking, cognitive presence, and computer conferencing in distance education. American Journal of Distance Education, 15(1), 7-23.

Garrison, D. R., Anderson, T., \& Archer, W. (2010). The first decade of the community of inquiry framework: A retrospective. The Internet and Higher Education, 13(1), 5-9.

Garrison, D. R. \& Akyol, Z. (2015). Toward the development of a metacognition construct for communities of inquiry. The Internet and Higher Education, 24, 66-71.

Jansen, B. A. (2011). Inquiry Unpacked: An Introduction to Inquiry-Based Learning. Library Media Connection, 29(5), 10-12.

Kent, C., Laslo, E., \& Rafaeli, S. (2016). Interactivity in online discussions and learning outcomes. Computers \& Education, 97, 116-128.

Kovanović, V., Gašević, D., Joksimović, S., Hatala, M., \& Adesope, O. (2015). Analytics of communities of inquiry: Effects of learning technology use on cognitive presence in asynchronous online discussions. The Internet and Higher Education, 27, 74-89.

Kozan, K. (2016). The incremental predictive validity of teaching, cognitive and social presence on cognitive load. The Internet and Higher Education, 31, 11-19.

Kula, S.G. (2009). Arastirmaya dayali fen ogrenmenin ogrencilerin bilimsel surec becerileri, basarilari, kavram ogrenmeleri ve tutumlarina etkisi (Unpublished master's thesis). Marmara University, Istanbul.

Lim, B. R. (2001). Guidelines for designing inquiry-based learning on the Web: Online professional development of educators (Unpublished doctoral dissertation). Indiana University, Bloomington.

Lim, J. \& Richardson, J. C. (2016). Exploring the effects of students' social networking experience on social presence and perceptions of using SNSs for educational purposes. The Internet and Higher Education, 29, 31-39. 
Ma, J., Han, X., Yang, J., \& Cheng, J. (2015). Examining the necessary condition for engagement in an online learning environment based on learning analytics approach: The role of the instructor. The Internet and Higher Education, 24, 26-34.

Morueta, R. T., López, P. M., Gómez, Á. H., \& Harris, V. W. (2016). Exploring social and cognitive presences in communities of inquiry to perform higher cognitive tasks. The Internet and Higher Education, 31, 122-131.

Oliveira, I., Tinoca, L. \& Pereira, A. (2011). Online group work patterns: How to promote a successful collaboration. Computers \& Education, 57, 1348-1357.

Ozturk, E. (2012). Arastirma toplulugu olceginin Turkceye uyralanmasi: Geçerlik ve guvenirlik calismasi. Ilkogretim Online, 11(2), 408-422.

Quintana, C., Zhang, M., \& Krajcik, J. (2005). A framework for supporting metacognitive aspects of online inquiry through software-based scaffolding. Educational Psychologist, 40(4), 235-244.

Remesal, A. \& Colomina, R. (2013). Social presence and online collaborative small group work: A socioconstructivist account. Computers \& Education, 60, 357-367.

Scott, K. S., Sorokti, K. H., \& Merrell, J. D. (2016). Learning "beyond the classroom" within an enterprise social network system. The Internet and Higher Education, 29, 75-90.

Shaw, R.S. (2013). The relationships among group size, participation, and performance of programming language learning supported with online forums. Computers \& Education, 62, 196-207.

Shea, P. et al. (2010). A re-examination of the community of inquiry framework: Social network and content analysis. The Internet and Higher Education, 13(1), 10-21.

Shea, P. \& Bidjerano, T. (2012). Learning presence as a moderator in the community of inquiry model. Computers \& Education, 59(2), 316-326.

Shea, P., Hayes, S., Uzuner-Smith, S., Gozza-Cohen, M., Vickers, J., \& Bidjerano, T. (2014). Reconceptualizing the community of inquiry framework: An exploratory analysis. The Internet and Higher Education, 23, 9-17.

Szeto, E. (2015). Community of Inquiry as an instructional approach: What effects of teaching, social and cognitive presences are there in blended synchronous learning and teaching?. Computers \& Education, 81, 191-201.

Tatar, N. (2006). Ilkogretim fen egitiminde arastirmaya dayali ogrenme yaklasiminin bilimsel surec becerilerine, akademik basariya ve tutuma etkisi. (Unpublished doctoral dissertation). Gazi University, Ankara.

Turel, Y. K. (2016). Relationships between students' perceived team learning experiences, team performances, and social abilities in a blended course setting. The Internet and Higher Education, 31, 79-86.

Wisneski, J. E., Ozogul, G., \& Bichelmeyer, B. A. (2015). Does teaching presence transfer between MBA teaching environments? A comparative investigation of instructional design practices associated with teaching presence. The Internet and Higher Education, 25, 18-27.

Yang, J. C., Quadir, B., Chen, N. S., \& Miao, Q. (2016). Effects of online presence on learning performance in a blog-based online course. The Internet and Higher Education, 30, 1120. 
Yang, S. H. (2016). Conceptualizing effective feedback practice through an online community of inquiry. Computers \& Education, 94, 162-177.

Yurdakul, B. (2005). Yapılandırmacılık. In Ö. Dmirel (Ed.), Egitimde yeni yonelimler (pp. 38-66). Ankara: Pegem A.

Zhang, M., \& Quintana, C. (2012). Scaffolding strategies for supporting middle school students' online inquiry processes. Computers \& Education, 58(1), 181-196.

Zydney, J. M., deNoyelles, A., \& Seo, K. K.-J. (2012). Creating a community of inquiry in online environments: An exploratory study on the effect of a protocol on interactions within asynchronous discussions. Computers \& Education, 58(1), 77-87.

Correspondence: Mustafa Serkan Gunbatar, Assistant Professor, Department of Computer Education and Instructional Technologies, Faculty of Education, Yuzuncu Yil University, Van, Turkey 